\title{
FUNGAL FLORA AND AFLATOXINS (AFTS) CONTAMINATION OF GARRI IN PARTS OF AKWA IBOM STATE, NIGERIA
}

\author{
${ }^{1 \dagger}$ Sanyaolu, A.A.A. ${ }^{1}$ Matthew, J.E. and ${ }^{1}$ Akpasoh, E.E. \\ ${ }^{1}$ Department of Botany and Ecological Studies, \\ Faculty of Science, University of Uyo, Uyo - Akwa Ibom State, Nigeria. \\ ${ }^{\dagger}$ Corresponding author's email: adeniyisanyaolu@uniuyo.edu.ng \\ (Received: $31^{\text {st }}$ December, 2018; Accepted: $7^{\text {th }}$ March, 2019)
}

\section{ABSTRACT}

Garri, a pre-eminent staple diet in Nigeria, accounts for over $70 \%$ of the total calorie intake of more than $50 \%$ of Nigeria's population. This study investigated the fungal flora and the level of aflatoxin contamination of garri sold in two open markets (Uyo and Oron) in Akwa Ibom State, Nigeria. Samples randomly purchased from each market were aseptically transported to the laboratory and cultured for fungi. Identification of fungal cultures was done using morphology of the isolates. Three subsamples from each location were extracted, spotted and quantified for aflatoxins B1, B2, G1 and G2. Values were the means from 3 subsamples. Data were processed using T-test and means separated for statistical significance at $\mathrm{P}<0.05$ using the Least Significant Difference (LSD). Fungi isolated from both markets were Fusarium verticolloides, Cercospora sp, Aspergillus flavus, $A$. niger and $A$. parasiticus. From the Uyo samples, the following additional fungi were found Fusarium solanii and A. parasiticus. Aflatoxin B1 (AFB1) was significantly higher $(\mathrm{P}<0.05)$ in samples from Oron $(21.67 \mu \mathrm{g} / \mathrm{kg})$ compared to Uyo $(3.33 \mu \mathrm{g} / \mathrm{kg})$. Aflatoxins B2, G1 and G2 were below detection limit in the samples. AFB1 in garri samples from these two markets in Akwa Ibom State is being reported, probably for the first time.

Keywords: Garri, Fungal flora, aflatoxins, Open market and Akwa Ibom state

\section{INTRODUCTION}

The diet of many indigenous African people is supplemented with cassava products such as garri, fufu, tapioca etc in their varied forms (Bottalico and Perrone, 2002). In Nigeria, garri, a preeminent staple food, accounts for over $70 \%$ of the total cassava consumption (Ezeh et al., 2012). If the growth and metabolism of microorganisms are not controlled, they are capable of altering the condition of any food, causing food spoilage (Liu et al, 2013) and poisoning. Food poisoning is an illness resulting from the consumption of food containing toxin(s) secreted into it by the contaminating microorganism(s) (Bottalico and Perrone, 2002).

In the processing of garri from cassava, the cassava is peeled, washed, grated and thereafter dehydrated under pressure, before being finally fried, packaged and stored preparatory for sales in the market (Hartley et al., 1963). Expectedly, garri is prone to microbial contamination if all of the above processes are not carried out in tandem with strict hygienic practices (Alum et al., 2016). Mycotoxin contamination of food materials in the open markets in Nigeria has been reported in previous studies (Ezeh et al., 2012 and Rubert et al.., 2013). Aflatoxins (AFTs) appear to be more wide spread than all the other mycotoxins (Osuret et al., 2016). AFTs are metabolites of the fungi, Aspergillus flavus and Aspergillus parasiticus (Adebayo-Tayo and Ekerete, 2010). Ingestion of AFT contaminated food is known to be of severe toxicological implication in humans and animals (Atarwodi et al., 1994) where they could cause chronic liver disease (Hutanasu et al., 2009). According to a 2018 report of the European Food Safety Authority (EFSA), AFTs in food are known carcinogenic and teratogenic agents. Other economic debacles associated with AFTs include low yields of food and fiber crops (Cheeke, 1998).

In view of the enormous economic and health implications of AFTs in food, this work set out to determine the types of fungal flora associated with garri and their toxic metabolites in parts of Akwa Ibom State and to identify and quantify the presence of AFTs contamination in these garri samples. 


\section{MATERIALS AND METHODS}

Isolation and Identification of Fungal Flora from Garri Samples

About $50 \mathrm{~g}$ of garri samples were randomly purchased from five sellers from each of the following markets: Itam market, Uyo $\left(5^{\circ} 03^{\prime} 32.1^{\prime \prime} \mathrm{N} 7^{\circ} 53^{\prime} 22.1^{\prime \prime} \mathrm{E}\right)$ and Oron main

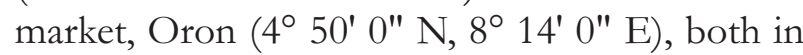
Akwa Ibom State. These samples were aseptically transported in sterile containers and sent to the laboratory where each of them were bulked and thoroughly mixed under aseptic condition. From a total $250 \mathrm{~g}$ bulked sample from each of the market, exactly $10 \mathrm{~g}$ was weighed out and serial dilution up to $10^{3}$ was done using the method of Nwachukwu (2000). From each of these, $1 \mathrm{ml}$ was cultured in sterile plates containing freshly prepared Potato Dextrose Agar (PDA) containing antibiotic and lactic acid. This was thereafter incubated at $31{ }^{\circ} \mathrm{C}$ until fungal growth of the full diameter of each plate was obtained. There was repeated sub culturing of each of the plates until pure plates were achieved. Identification of each of the fungus was done based on the morphologic characters of each fungus. The plates were then compared with the descriptions given by Talbot (1971); Deacon (1980) and Bryce (1992) for identification.

\section{Extraction and Quantification of Aflatoxins (AFTs) in Samples}

These were carried out in the pathology laboratory of the International Institute of

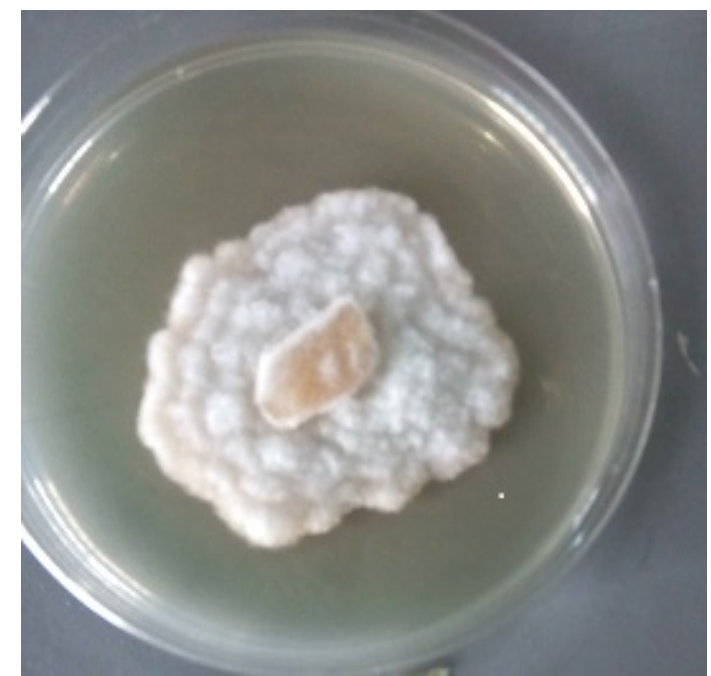

Plate 1: Fusarium verticolloides $\times 0.5$
Tropical Agriculture (IITA), Ibadan-Nigeria. The UK standard was adopted for the entire procedure. The method of Bankole and Adebanjo (2003) was used for the extraction, spotting and quantification of AFTs in samples using the High Performance Thin Layer Chromatography (HPTLC) Plate, U-V Light Scanner (ENF260C/FE) and CAMAG TLC Scanner 3 (set at a detection limit of below $1 \mu \mathrm{g} / \mathrm{kg}$ ). Recovery of toxin was $>85 \%$. Values reported for AFTs load were the means of three subsamples per sample from each location.

\section{RESULTS}

\section{Mycoflora from Garri Samples}

The mycoflora associated with garri samples from both locations were almost identical. These include Fusarium sp (Plate 1), Cercospora sp (Plate 2), Aspergillus flavus (Plate 3) and Aspergillus niger (Plate 4). From the Uyo samples however, $A$. parasiticus (Plate 5) was found in addition to all the others above.

\section{Aflatoxins(AFTs) in Samples}

The results as presented in table 1 show that aflatoxin B1 (AFB1) was present in the garri samples from both open markets. However, aflatoxins B2, G1 and G2 were below the detectable limit of $1 \mu \mathrm{g} / \mathrm{kg}$ in all the samples. AFB1 in Uyo samples had a mean value of 3.33 $\mu \mathrm{g} / \mathrm{kg}$, a value significantly lower $(\mathrm{p}<0.05)$ than the mean value of $21.67 \mu \mathrm{g} / \mathrm{kg}$ present in samples from the Oron open market.

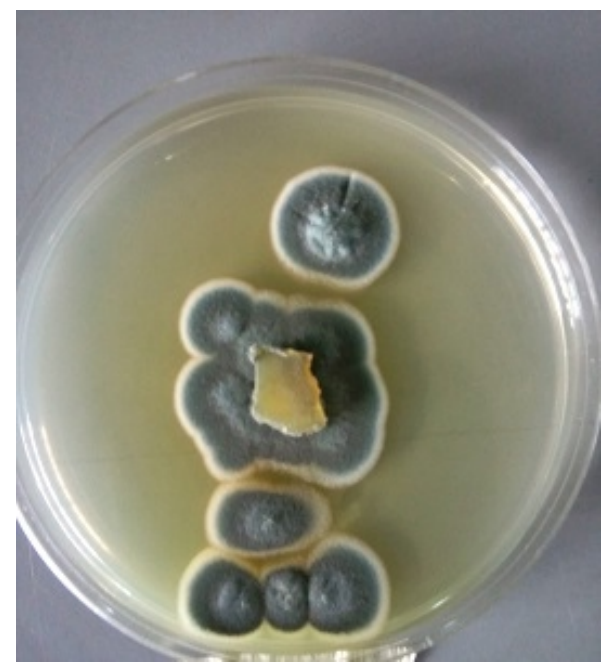

Plate 2: Cercospora sp $\times 0.5$ 


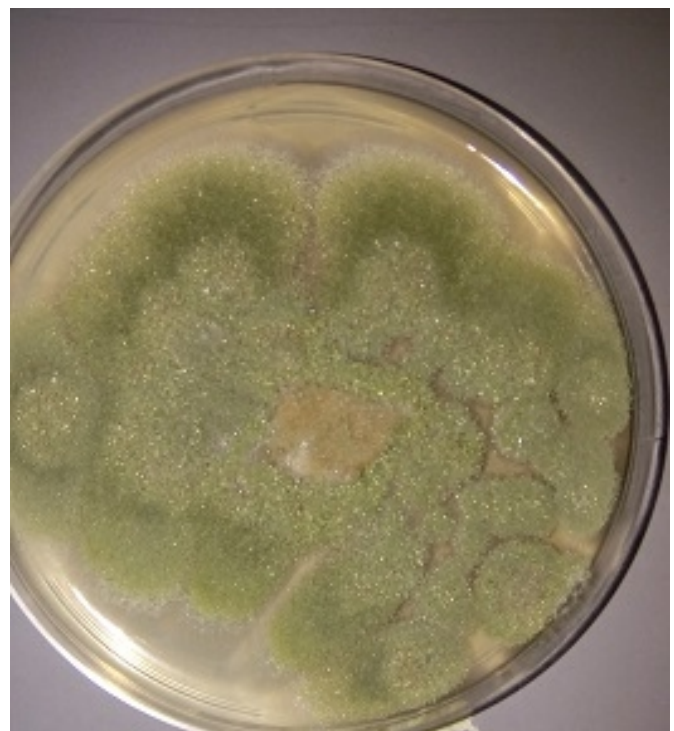

Plate 3: Aspergillus flavus $\times 0.5$

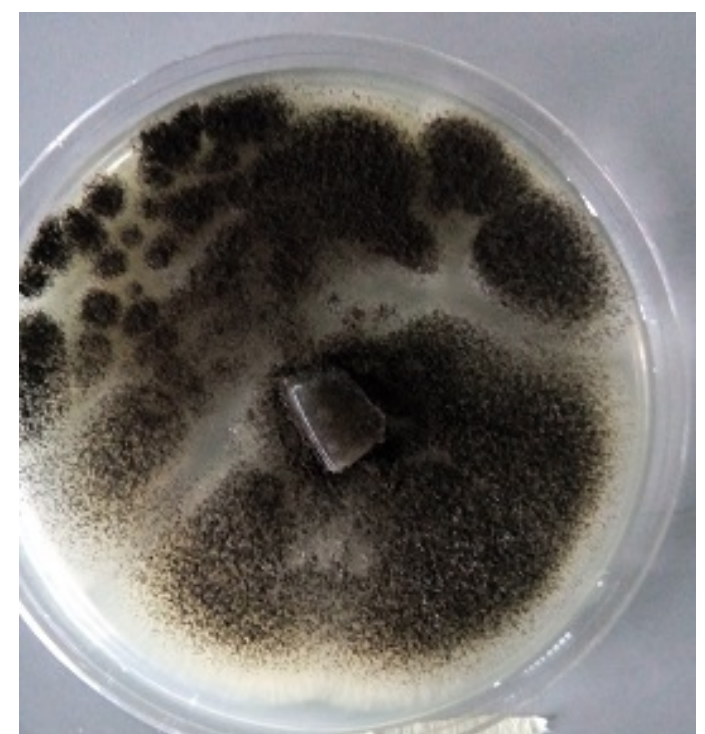

Plate 4: Aspergillus niger $\times 0.5$

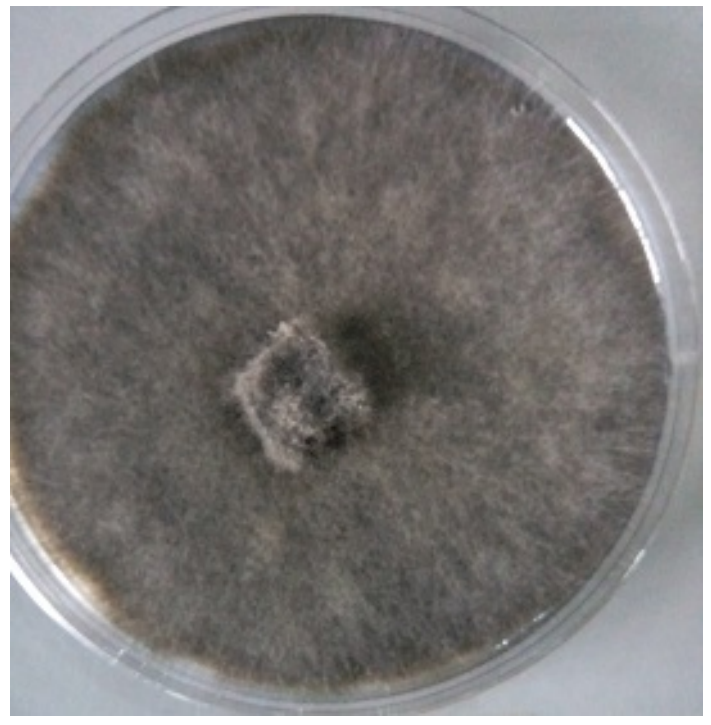

Plate 5: Aspergillus parasiticus $\times 0.5$

Table 1: Aflatoxins Load $(\mu \mathrm{g} / \mathrm{kg})$ in Garri Samples from Uyo and Oron

\begin{tabular}{llcccc}
\hline Sample & Location & $\begin{array}{c}\text { Mean } \pm \text { SEM } \\
\text { AFB1 }\end{array}$ & $\begin{array}{c}\text { Mean } \pm \text { SEM } \\
\text { AFB2 }\end{array}$ & $\begin{array}{c}\text { Mean } \pm \text { SEM } \\
\text { AFG1 }\end{array}$ & $\begin{array}{c}\text { Mean } \pm \text { SEM } \\
\text { AFG2 }\end{array}$ \\
\hline Garri & Uyo & $3.33 \pm 2.50^{\mathrm{a}}$ & 0 & 0 & 0 \\
Garri & Oron & $21.67 \pm 2.33^{\mathrm{b}}$ & 0 & 0 & 0 \\
\hline
\end{tabular}

Mean values carrying different superscripts are significantly different at $\mathrm{p}<0.05$. 


\section{DISCUSSION}

Microbiological sources of food contamination are more preponderant and are therefore of greater concern than other sources of contamination such as chemical and physical sources because of the quantum of illnesses associated with it (Scallan et al., 2011). In food safety issues therefore, microbiological considerations are of paramount importance.

The most palpable concern associated with fungal contamination of food is in connection with the production and deposition of mycotoxins on the food material. The most important genera of mycotoxigenic fungi are Aspergillus, Alternaria, Claviceps, Fusarium, Penicillium and Stachybotrys. (Yaling et al., 2008 and Averkieva, 2009). The results obtained from the present study showed that the garri sold in our open markets in Akwa Ibom state are contaminated by two fungal genera (i.e Aspergillus and Fusarium) out of these five notorious fungal genera earlier mentioned.

AFTs and fumonisins have been reported as being the most common mycotoxin (Wu et al., 2014), affecting not less than $25 \%$ of the world's agricultural food sources (Williams et al., 2004; Yard et al., 2013). Mycotoxins generally are produced by over 100 filamentous fungi containing some 400 secondary metabolites with toxigenic ability (Kabak et al., 2006). On its own, it has been reported that over 4.5 billion individuals in developing countries are at a risk of exposure to AFTs poisoning in food (Williams et al., 2004). AFTs have been reported to be present in rates above the permissible level of $20 \mu \mathrm{g} / \mathrm{kg}$ or $20 \mathrm{ppb}$ in staple foods such as cassava flour, groundnut and groundnut paste sold in some open markets in Kampala, Uganda (Osuret et al., 2016). Results from this study therefore leaves much to worry about as the mean value of $21.67 \mu \mathrm{g} / \mathrm{kg}$ of AFTB1 in garri samples from Oron market is above the permissible level in food. The far reaching implication of AFTB1 as a group 1 carcinogen in humans (Seo et al., 2011) as well as their hepatotoxic (Abdel-Wahhab et al., 2007) and immunosuppressive nature (Mehrzad et al., 2014) has been documented. By implication, apart from the obvious negative effects of AFTB1 poisoning in humans, it is also expected to have a colossal adverse effect on the socio-economic matrices of the society which include loss of human and animal life, increased cost in human health care and animal care, drop and or losses in livestock productivity, loss of forage plants and animal feeds, regulatory and research costs targeted at mitigating the effects of mycotoxin poisoning.

The fact that the other AFTs (B2, G1 and G2) were not detected in any of the samples does not necessarily indicate that they were altogether absent. Rather, it could be indicative of the fact that they were present below the detectable limit of $1 \mu \mathrm{g} / \mathrm{Kg}$. As such, an unwitting cumulative exposure to the sub lethal doses over a long time may eventually produce some undesirable effects on human health and well being.

In developed countries of Europe and the USA, stringent standards of evaluating and enforcing compliance to the permissible limits of mycotoxins in food have been well developed. In the developing countries of Africa however, there appears to be a lax and uncoordinated regulatory and enforcement regimes by the concerned agencies of government at ensuring compliance to the locally adopted permissible mycotoxin limits adopted by these countries.

The findings from this research may bear a subtle correlation with the increasing incidence of some debilitating cancer and organ failure experienced in Akwa Ibom state (Nwafor and Nwafor, 2018).

\section{CONCLUSION}

From available literature, this is probably a first report of AFTB1 contamination of garri samples sold in the open markets in Akwa Ibom state. This calls for the concern of all relevant stakeholders.

\section{REFERENCES}

Abdel-Wahhab M. A., Abdel-Galil M. M., Hassan A. M., Hassan N. H., Nada S. A., Saeed A. and el-Sayed, M.M. (2007). Zizyphus spina-christi extract protects against aflatoxin B1-intitiated hepatic carcinogenicity. African Journal of Traditional, Complementary and Alternative Medicine 4:248-256.

Adebayo-Tayo, B.C. and Ekerete, B.S. (2010). 
Effect of cultural conditions on exobiopolymer production and biomass growth by Pleurotus sajor-caju (Fr.) Quel, a Nigerian edible mushroom. Advances in Food Science, 32(2): 75-8128.

Alum, E. A., Urom, S.M.O.C. and Ben, C.M.A, (2016). Microbiological contamination of food: The mechanisms, impacts and prevention. Internal Journal of Scientific and Technology Research, 5(3): 65-78.

Atawodi, S.E., Atiku, A.A. and Lamorde, A.G. (1994). Aflatoxin contamination of Nigerian foods and feeding stuffs. Food and Chemical Toxicology, 32(1): 61-63.

Averkieva, O. (2009). Mycotoxins in grains harvested in 2008: Wheat mycotoxinscontamination LC-MS/MS Czech Repub. Microsoft. Mycotoxins Technical Article, Engormix. Communication 10.

Bankole, S. A. and Adebanjo A. (2003). Mycotoxins in food in West Africa: Current situation and possibilities of controlling it. African Journal of Biotechnology, 2(9): 254-263

Bottalico, A., Perrone, G., (2002). Toxigenic Fusarium species and mycotoxins associated with head blight in small-grain cereals in Europe. European Journal of Plant Pathology, 108 (7): 611-624.

Bryce, K. (1992). The fifth Kingdom. Mycologue Publications, Ontario. 412pp.

Cheeke, P.R. (1998). Mycotoxins in cereal grains and supplements. In: Cheeke, P.R. (Ed.): Natural Toxicants in Feeds, Forages, and Poisonous Plants. Interstate Publishers, Inc., Danville, IL, pp. 87-136.

Deacon, J.W. (1980). Introduction to Modern Mycology. Blackwell Scientific Publications, London. 197pp.

European Food Safety Association (EFSA) (2018). Aflatoxins in Food. Available on www. efsa.europa.eu/en/topics /topic/aflatoxins-food. Accessed on 15/10.2018.

Ezeh, C.I., Anyiro C.O., Obioma, N.Q., Maduagwu, O.C. (2012). Demand structure and the consumption of garri in Owerri North Local Government Area of Imo State, Nigeria. International Journal of Agriculture and Forestry, 2(6): 273-278

Hartley, R. D. Hesbitt, B.F., and Kelly, J. (1963). Toxic metabolites of Aspergillus flavus. Nature: 1056-1058

Hutanasu, C., Sfarti, C., Trifan, A., Hutanasu, M. and Stanciu, C., (2009). Aflatoxin contamination of food: additional risk factor for chronic liver diseases. Revista Medico-chirurgicala a Societatii de Medici si Naturalisti din Iasi, 113: 1061-1065

Kabak, B., Dobson, A. and Var, I. (2006). Strategies to prevent mycotoxin contamination of food and animal feed: A review. Critical Reviews in Food Science and Nutrition, 46(8): 593-619.

Liu, N.T., Lefcourt, A.M., Nou, X., Shelton, D.R. Zhang, G. and Lo, Y.M. (2013). Native microflora in fresh-cut produce processing plants and their potentials for biofilm formation. Journal of Food Protection, 76: 827-832.

Mehrzad, J., Devriendt, B., Baert, K. and Cox, E. (2014). Aflatoxin B1 interferes with the antigen presenting capacity of porcine 4 dendritic cells. Toxicology in Vitro, 28(4): 531-537.

Nwachukwu, S.C.U. (2000). Enhanced rehabilitation of tropical aquatic environments polluted with crude petroleum using Candida utilis. Journal of Environmental Biology, 21(3): 241250.

Nwafor, C.C. and Nwafor, N.N. (2018). The pattern and distribution of cancers in Akwa Ibom State. Nigerian Journal of Clinical Practice, 21(5): 603-608.

Osuret, J., Musinguzi, G., Mukama, T., Halage, A.A., Natigo, A.K.,. Ssempebwa, J.C. and Wang, Jia-Sheng (2016). Aflatoxin contamination of selected staple foods sold for human consumption in Kampala markets, Uganda. Journal of Biological Sciences, 16: 44-48.

Rubert, J., Fapohunda, S.O., Soler, C., Ezekiel, C.N., Maines, J. and Kayode, F. (2013). A survey of mycotoxins in random streetvended snacks from Lagos, Nigeria, using QuEChERS-HPLC-MS/MS. Food Control,32(2): 673-677.

Scallan, E, Hoekstra, RM, Angulo, F.J., Tauxe, 
R.V., Widdowson, M.A., Roy, S.L, Jones, J.L. and Griffin, P.M. (2011). Foodborne illness acquired in the United States -major pathogens. Emerging Infectious Diseases, 17(1): 7-15.

Seo, J. H., Min, W. K., Kweon, D. H., Park, K., and Park, Y. C. (2011). Characterization of monoclonal antibody against aflatoxin B1 produced in hybridoma $2 \mathrm{C} 12$ and its single-chain variable fragment expressed in recombinant Escherichia coli. Food Chemistry, 126: 1316-1323.

Talbot, O.H.K. (1971). An Introduction to Mycology. Leonard Hill Publishers, London. 252pp

Williams, J. H., Phillips, T. D., Jolly, P. E., Stiles, J. K., Jolly, C. M., and Aggarwal, D. (2004). Human aflatoxicosis in developing countries: a review of toxicology, exposure, potential health consequences, and interventions. American Journal of
Clinical Nutrition, 80:1106-1122.

Wu, F., Groopman, J.D. and Pestka, J.J. (2014). Public health impacts of foodborne mycotoxins. Annual Review of Food Science and Technology, 5:351-372.

Yaling, W., Tongjie, C., Guozhong, L., Chunsan, Q. Huiyong, D., Meiling, Y., Bert-Andree, Z. and Gerd, S. (2008). Simultaneous detection of airborne aflatoxin, ochratoxin and zearalenone in poultry house by immunoaffinity column and high performance liquid chromatography. Environmental Research, 107: 139-144

Yard, E. E., Daniel, J. H., Lewis, L. S., Rybak, M. E., Paliakov, E. M., Kim, A. A., Montgomery, J. M., Bunnell, R., Abudo, M. U., Akhwale, W., Breiman, R. F., and Sharif, S. K. (2013). Human aflatoxin exposure in Kenya, 2007: A crosssectional study. Food Addit. Contam. Part A, 30:1322- 1331. 